\title{
Cytotoxic activity of in vitro Bacopamonnieri different extracts
}

\author{
Nesma F. Hamed ${ }^{1}$, Awatef M.E. Badr Elden ${ }^{2 \star}$, Rafat Elsanhoty ${ }^{1}$, \\ and Ahmed Abd Elmaksoud'
}

${ }^{1}$ Industrial Biotechnology Department, Genetic Engineering and Biotechnology Research Institute (GEBRI), University of Sadat City, Egypt.

2Plant Biotechnology Department, Genetic Engineering and Biotechnology Research Institute (GEBRI), University of Sadat City, Egypt.

Corresponding author: Email: awatef.badrelden@gebri.usc.edu.eg

\begin{abstract}
Bacopamonnieri (BM) which is commonly known as "Brahmi," belongs to the family Scrophulariaceae, $(B M)$ is an herbaceous plant traditionally used from time immemorial in Ayurvedic and folklore medicines, found throughout the Indian subcontinent in wet, damp and marshy areas. Tissue culture studies were performed on Bacopamonnieri (Brahmi). Nodal explants containing preformed axillary buds were used as the starting material. Sterilized explants were aseptically cultured on MS medium supplemented with different plant growth regulators. This study aimed at evaluating the anticancer activity of extraction of (BM) with different solvents according to polarity, namely (methanol, chloroform, and acetone) against two different cell lines of colorectal cancer. Cell cytotoxicity effects of each extract of (BM)was carried out by means of3-(4,5-dimethylthiazol-2-yl)-2,5-diphenyltetrazolium bromide(MTT) cell viability assay using (human colorectal carcinoma) hct116 and (human epithelial colorectal adenocarcinoma) caco 2 cell lines. The acetone extract showed the potent cytotoxicity at 48 hr (IC50 6.79-6.1 $\mu \mathrm{g} / \mathrm{MI})$ for hct116 and Caco2, respectively.
\end{abstract}

Key words: Bacopamonieri, tissue culture, MTT assay, acetone extract.

\section{INTRODUCTION}

Medicinal plants are considered one of the essential sources of life-saving drugs for the majority of the world's population. Natural products derived from medicinal plants act as fertile ground both to be used as Phytotherapy and to isolate phytochemicals with interesting pharmacological features for treatment of infectious diseases and cancer, which is subjected to be the major cause of death in this century. In-vitro regeneration holds enormous prospective for the production of high-quality plant-based medicine (Tripathi et al., 2003).

Bacopamonnieri (BM) is a medicinal plant belonging to the Scrophulariaceae family, and it's commonly called Brahmi (Srivastava et al., 2017).In the conventional system of medicine in Indian (Ayurveda) as a memory enhancer, antipyretic, antioxidant, anti-inflammatory, sedative analgesic, and anti-epileptic agent (Sharma, 2005; Bhusari et al., 2013).Plant Tissue Culture is application of biotechnology for growing and multiplication of the cells, 
tissues, and organs of the plant in a controlled environment of light, temperature, $\mathrm{pH}$, etc.(Lakhera, $\mathrm{K}$ et al., 2018) and also plant cell and organ cultures are promising technologies to obtain plant-specific valuable metabolites (Verpoorte et al., 2002). Cell and organ cultures have higher rate of metabolism than field-grown plants because the initiation of organ and cell growth in culture leads to the fast proliferation of cells/organs and to a condensed biosynthetic cycle (Rao and Ravishankar, 2002). plant cell/organ cultures are not limited by environmental, ecological, and climatic conditions, and cells/organs can thus proliferate at higher growth rates than the whole plant in cultivation(Naik et al., 2017). Several biotechnological advances have been developed in tissue culture that improve secondary metabolite production such as optimization of cultural conditions, selection of high-producing strains of lines, precursor feeding, elicitation, metabolic engineering, transformed root cultures, micropropagation, and bioreactor cultures, among others (Sarin, 2005; Murthy et al., 2014). Cancer generally defined as a term for a large group of diseases specified by uncontrolled growth of cells that produce invasion of surrounding tissues and cause metastasis (Bazrafshan and Lotfi, 2016). Colorectal cancer (CRC) consider as the third most commonly diagnosed cancer and is a leading cause of cancer-related deaths ( Ferlay et al., 2015 ) . Colorectal carcinogenesis is a complex multistep process that involving progressive disruption of intestinal epithelial-cell proliferation, differentiation, apoptosis, and survival mechanisms (Calvert and Frucht, 2000). The using of cancer drugs (chemotherapy, biological therapies, and hormones) is the current choice for the treatment of metastatic cancer(Pérez-Herrero and FernándezMedarde, 2015).Chemotherapeutic drugs are based on compounds that primarily inhibit the fast proliferation of cancer cells but, unfortunately, due to the non-selectivity of the drugs that may target the healthy organs, so they also inhibit the rapid growth needed for the maintenance other healthy tissues which lead to the undesirable side effects (Chabner, and Roberts, 2005). MTT assay is a quantitative, reliable, sensitive, and colorimetric method for the determination of cell survival and proliferation (Shashi et al., 2006).MTT assay was conducted to measure the median inhibitory concentration (IC50) of compounds After 48 hours of incubation of hct116 and caco 2 cells in 96-well plate at a density of $2.0 \times 104$ in $200 \mu \mathrm{L}$ of medium per well.

Aim of the present research is to perform the in vitro cytotoxic prospective of BM different extracts (methanolic, chloroform, and acetone extract ) against two different colon cancer cell lines ( hct-116, caco-2 ) .The acetone extract showed the highest cytotoxicity. 


\section{PATIENTS AND METHODS}

\section{Plant material and sterilization of explants}

Young and healthy plants collected from the farm of Genetic Engineering and Biotechnology Research Institute (GEBRI), University of Sadat City (USC), Egypt. Shoot tips explants were surface sterilized by cleaning thoroughly under running tap water for $15 \mathrm{~min}$ followed by immersing in 10\% (v/v) Clorox for 5-7 min. They were washed thrice with double distilled water and kept in laminar airflow. The cleaned explants were surface sterilized with 5 min treatment with $0.1 \%(\mathrm{w} / \mathrm{v})$ $\mathrm{HgCl} 2$ under aseptic conditions and washed five times with sterile double distilled water to remove traces of $\mathrm{HgCl} 2$ before cultured (Mohanta and Sahoo, 2014). Following disinfection, explants were cultured in a hormone-free MS medium (Murashige and Skoog, 1962) supplemented with (1mg/l BA $30 \mathrm{~g} / \mathrm{L}$ sucrose and $7 \mathrm{~g} / \mathrm{L}$ agar), $\mathrm{pH}$ was adjusted to 5.7 with $\mathrm{KOH}$. The explants were grown in a 16 hrs light photoperiod under an irradiance of 2,000 lux, and an average temperature of $250 \mathrm{C} \pm 20 \mathrm{C}$ for six weeks at Germplasm Conservation and Gene transfer Laboratory at Genetic Engineering \& Biotechnology Research Institute (GEBRI).

\section{In vitro shoot regeneration}

Effect of BA and Auxin (NAA, IAA, and IBA) at different concentrations on shoot proliferation

In order to achieve shoot proliferation of Bacopamonnieri (shoots of about $2 \mathrm{~cm}$ long with 2-5 leaves) obtained from the previous stage which is cultured in tissue culture jars $(350 \mathrm{ml})$ containing $60 \mathrm{ml}$ MS medium supplemented with $1 \mathrm{mg} / \mathrm{l}$ benzyl amino purine (BA) and auxin, Napthaline acetic acid (NAA), Indol acetic acid (IAA) and Indol -3-byuteric acid (IBA) at different concentrations $(0.0,0.2$, 0.4 and $0.6 \mathrm{mg} / \mathrm{l})$ each alone. After three subcultures, data were recorded as a number of shoots and shoot length (cm)/culture (jar).

In vitro roots induction and acclimatization of plants

For rooting, shoots raised from in vitro proliferation $(3-5 \mathrm{~cm}$ long) were excised and transferred to MS basal medium containing $30 \mathrm{gl}$ sucrose and $7 \mathrm{~g} / \mathrm{l}-1$ agar. The medium was further supplemented with1mg/l IBA for four weeks (Kaur et al.,2013). The rooted plantlets were transferred to $5 \mathrm{~cm}$ plastic pots containing peatmoss and sand soil in the ratio of 3:1. In vitro plants were finally transferred to a greenhouse where $98 \%$ of plants survived fig 1. Then whole plant was dried in an oven at $42^{\circ} \mathrm{C}$ (Kahol et al., 2004). For two days, then dried plant was grained to get coarse powder to be subjected to suitable extraction process. 


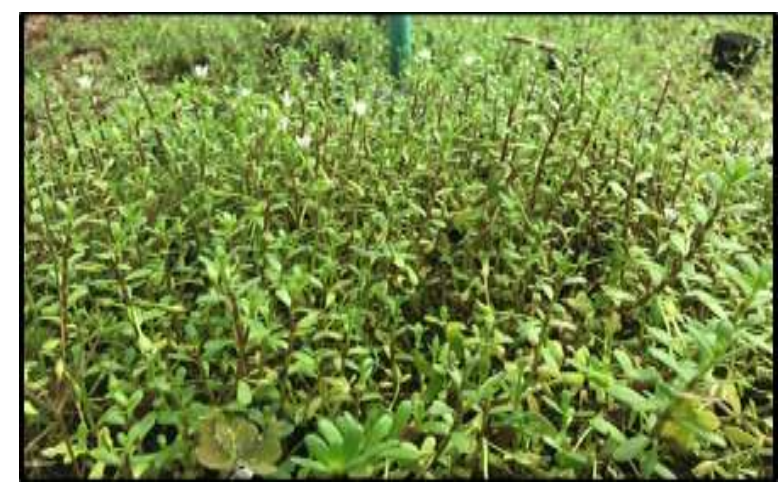

Fig 1. Acclimatization of Bacopamonnierin greenhouse.

\section{Extraction Preparation}

The dried plant material was coarsely powdered; the coarse powder of (BM) $(90 \mathrm{~g})$ was extracted with $1200 \mathrm{ml}$ of different solvents according to polarity, namely methanol, chloroform, and acetone using a Soxhlet apparatus set at $500 \mathrm{C}$ for $3 \mathrm{hrs}$. The extract was filtrated and dried under reduced pressure (Phrompittayarat et al., 2007).

\section{Cytotoxicity assay of Bacopamonnieri extracts}

\section{Sample preparation}

It was prepared by dissolving $10 \mathrm{mg}$ of each extract in $1 \mathrm{mIDimethyl} \mathrm{sulfoxide} \mathrm{(DMSO).}$ These solutions were filtered and stored at $4^{\circ} \mathrm{C}$ until used.DMSO control was also prepared and used in both the cell line.

\section{Cell line}

Caco-2 and HTC-116 cells obtained from Holding Company for Biological Products \& Vaccines (VACSERA, Egypt). In the T-75 sterile tissue culture flask, Caco-2 cells were grown using Dulbecco's Modified Eagle's Medium (DMEM) (Huang et al., 2014) while HTC-116 cells were incubated in Roswell Park Memorial Institute (RPMI)-1640 medium
(Hussien et al., 2013). Both were supplemented with heat-inactivated $10 \%$ FCS (fetal calf serum) and1\% antibiotic solution (a mixture of $100 \mu \mathrm{g} / \mathrm{ml}$ streptomycin and 100 $\mathrm{U} / \mathrm{ml}$ penicillin. Cells were maintained at $37^{\circ} \mathrm{C}$ using $\mathrm{CO} 2$ incubator under a mixture of air $(95 \%)$ and carbon dioxide (5\%). Cells were dissociated using $0.25 \%$ trypsin and were subcultured into $75 \mathrm{~cm} 2$ flasks and 96-well plates (TPP-Swiss). Each extract fraction was suspended in cell culture medium and diluted to appropriate concentrations.

\section{In vitro cytotoxicity (MTT assay)}

Viability of caco2 and hct116 cell lines was assessed by the MTT assay, as described by Mossman(Mossman, 1983). This assay was carried out by adding $0.5 \mathrm{~mL}$ of each extract fraction at the concentrations of $(5000 \mu \mathrm{g} / \mathrm{mL}$, $2500 \mu \mathrm{g} / \mathrm{mL}, \quad 1250 \mu \mathrm{g} / \mathrm{mL} \quad 625 \mu \mathrm{g} / \mathrm{mL}$ and $312.5 \mu \mathrm{g} / \mathrm{mL}, \quad 156.25 \mu \mathrm{g} / \mathrm{mL}, \quad 78.125 \mu \mathrm{g} / \mathrm{mL}$, $39.06 \mu \mathrm{g} / \mathrm{mL}, \quad 19.53 \mu \mathrm{g} / \mathrm{mL}, \quad 9.76 \mu \mathrm{g} / \mathrm{mL}$ and $4.88 \mu \mathrm{g} / \mathrm{mL}$ )for 48 hours. Treated cell lines were microscopically examined for detection of morphological changes and detached cells. Cell growth calculated by comparing the absorbance of treated versus untreated cells. Cells treated with an equivalent concentration of DMSO were used as negative control.Dead cells washed-out using phosphate buffer saline, pH $7.2 \pm 0.2$ (PBS-0.05\% Tween). Residual live cells treated with $0.5 \%$ MTT stain as $25 \mu \mathrm{l} /$ well. Plated were incubated for 3-4 hrs. at $370 \mathrm{C}$ in the dark. Developed intracytoplasmic MTT formazan crystals dissolved using $0.05 \mathrm{ml}$ Dimethyl sulphoxide (DMSO) for 30 minutes on plate shaker.The resulting formazan product was dissolved in $0.4 \%$ acidified isopropanol.Optical densities OD was 


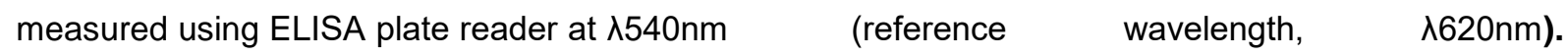

\section{RESULTS}

Effect of BA and Auxin (NAA, IBA, proliferating shoots significantly enhanced the and (AA) at Different Concentrations on Shoot Proliferation

Proliferation shoots were achieved after three subcultures in all cultures on MS medium supplemented with $1 \mathrm{mg} / \mathrm{l} \mathrm{BA}$ and different concentrations of auxin NAA, IBA and IAA $(0.0,0.2,0,4,0.6 \mathrm{mg} / \mathrm{l})$. The number of percentage of bud break and healthy shoots formation at NAA. The axillary bud break response increased with increased concentration of auxin from $0.2-0.6 \mathrm{mg} / \mathrm{l}$. A maximum shoots proliferation response of 350 was obtained on MS medium supplemented with $0.6 \mathrm{mg} / \mathrm{l} \mathrm{NAA}$ (Table $1 \mathrm{fig} 2$ ).

Table 1.Effect of MS medium supplemented with $1 \mathrm{mg} / \mathrm{l} \mathrm{BA}$ and different concentrations of NAA, IBA and IAA on shoot proliferation of Bacopamonnieriin vitro after three subcultures

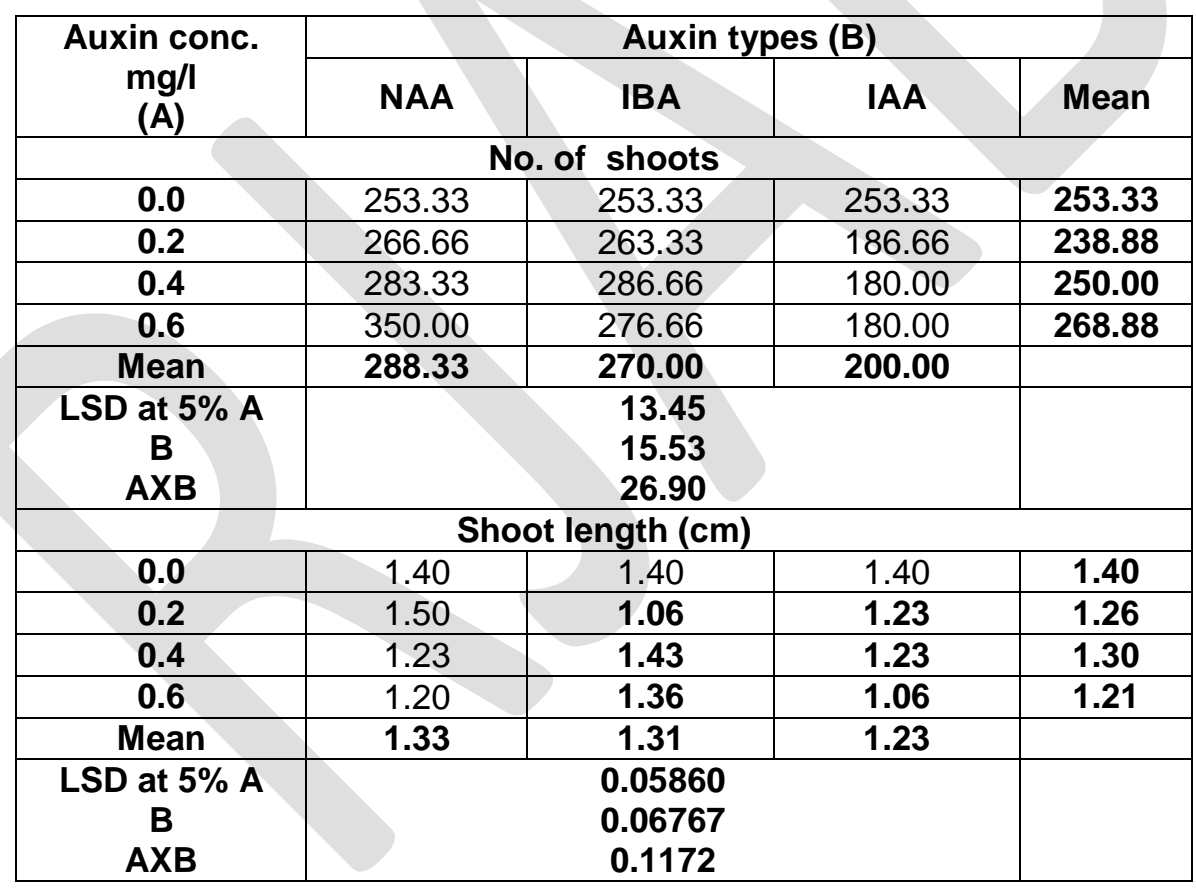




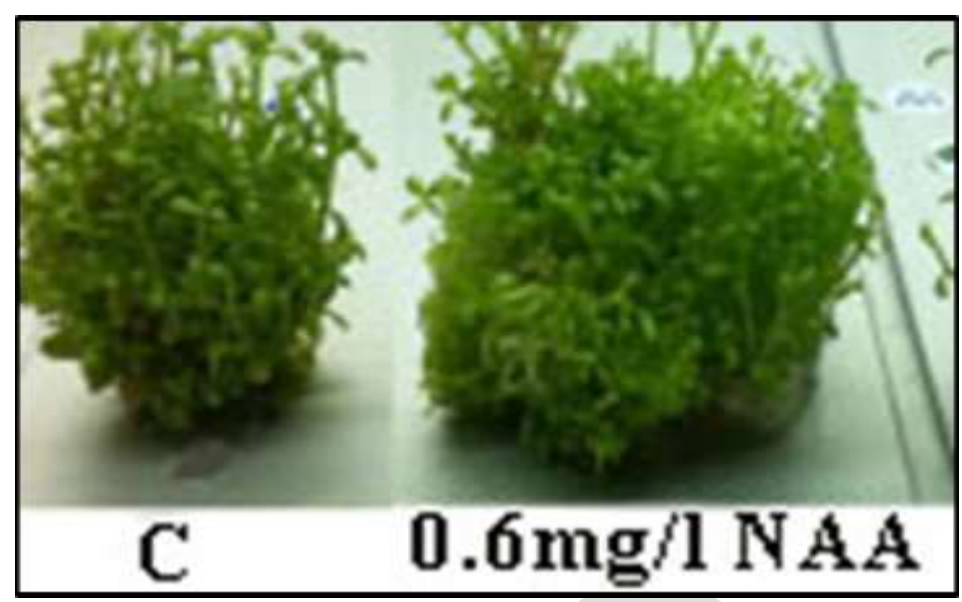

Fig 2. In vitro shoot proliferation of Bacopa after three subcultures on MS medium supplemented with $1 \mathrm{mg} / \mathrm{l} \mathrm{BA}$ and $0.6 \mathrm{mg} / \mathrm{INAA}$

\section{IC50 using MTT assay}

To examine the anticancer efficacy of BM different extracts, the viability of HCT-116 and caco2 cells was determined by MTT cell proliferation assay after $48 \mathrm{hr}$. Metahol extract showed an IC50 concentration $14.99 \mu \mathrm{g} / \mathrm{mland} 8.42 \mu \mathrm{g} / \mathrm{ml}$ against hct116 and caco2 cell lines respectively, chloroform extract show $14.26 \mu \mathrm{g} / \mathrm{ml}$ and $24.16 \mu \mathrm{g} / \mathrm{ml}$ against hct116 and caco2 cell lines respectively and acetone extract show $6.79 \mu \mathrm{g} / \mathrm{ml}$ and $6.10 \mu \mathrm{g} / \mathrm{ml}$ against hct116 and caco2 cell lines respectively Figure $3,4$.
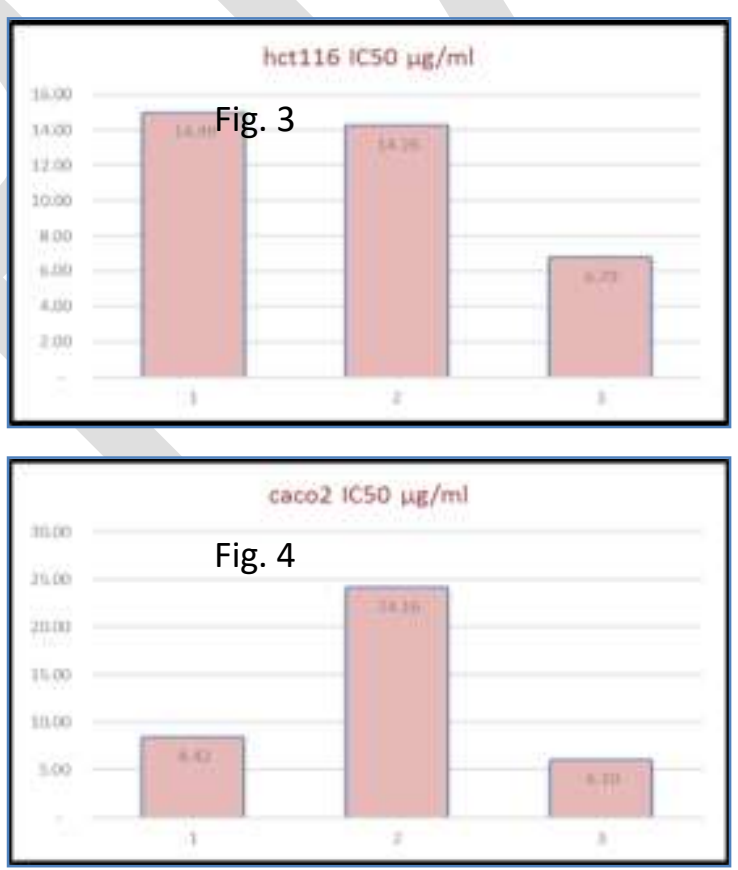

Figures 3,4 . Show cytotoxicity of BM different extracts (methano, chloroform and acetone) Symbolizes (1,2and 3) for each extract solvent methanol, chloroform and acetone respectively. 


\section{DISCUSSION}

Natural products have regarded as important sources that could produce potential chemotherapeutic agents (Prakash et al., 2011). Plant-derived compounds, in particular have gained importance in anticancer therapy, and some of the new chemotherapeutic agents currently available for use include paclitaxel, vincristine, podophyllotoxinandcamptothecin, a natural product precursor from water-soluble derivatives. Obviously natural products are extremely an important source of medicinal agents. Although there are some new approaches to drug discovery, such as computer-based molecular modeling design and combinatorial chemistry, none of them can replace the importance of natural products in drug discovery and development (Jagetia and Rao, 2006).

The degree of growth, differentiation, and metabolite accumulation varies considerably with the medium constitution (Bhaskaran and Jayabalan, 2005). The optimum nutrient concentration is a critical determinant in controlling the growth of the cells/organs and the accumulation of secondary metabolites (Murthy et al., 2008).

Many studies that show the effect of combination of plant growth regulators (PGRS)showed best results on MS with $1 \mathrm{mg} / \mathrm{l}$ IAA and $1 \mathrm{mg} / \mathrm{I}$ IBA for culture initiation, multiple shoot proliferation, bud breakage, shoot length, shoot numbers and cluster formation (Showkat et al., 2010) In our current study BM highest shoot number (350) was obtained when we use NAA $(0.6 \mathrm{mg} / \mathrm{l})$, while the highest shoot length $(1.5 \mathrm{CM})$ was obtained when we use NAA $(0.2 \mathrm{mg} / \mathrm{l})$. Control response to longest shoots than other treatments. The effect of auxin was tested for in vitro shoot multiplication, and the multiplication rate declined on NAA supplemented MS medium. result of axillary bud of Bacopamonnieri induction and observed on medium containing $1.0 \mathrm{mg} / / \mathrm{BAP}$ (Kaur et al., 3013). The best performance for shoot multiplication was showed in MS medium supplemented with $1.5 \mathrm{mg} / \mathrm{l} \mathrm{BAP+}$ 0.5mg/l IAA (Kapil and Sharma, 2014).

Maximum shoots obtainedon MS medium supplemented with $1.5 \mathrm{mg} / \mathrm{BA}$ where, $1 \mathrm{mg} / \mathrm{BBA}$ was to be superior to give maximum leaves. Height shoot length was observed on MS medium free hormone (Badr Elden,2014). Optimum micropropagation with 34.9 elongated shoots per explant was recorded in Murashige and Skoog medium containing 1.5 $\mathrm{mg} / \mathrm{L} \mathrm{BAP}$ and $2.0 \mathrm{mMspermidine}$

(Haque et al.,2017)

The various available anticancer drugs have limited therapeutic potential because of their high toxicity and inefficiency in cancer therapy (Shishodia et al., 2007). Therefore, the development of novel agents from a natural source for treatment of cancer is highly regarded. Bacobamonerrie, as a nontoxic natural product, and it has anti-tumor activity (Peng, L et al., 2010). Bacopamonnieri is shown to have potent antitumor and anticancer activities (Warrier et al. 1993). There are many studies that show cytotoxicity of BM different extracts the dichloromethane (DCM)extract show the best result against Ehrlich ascites carcinoma (EAC)tumor-bearing mice since it showed the best cytotoxicity at 72 h (IC5041.0-60.0 $\mu \mathrm{g} / \mathrm{mL}$ ) (Mallick et al., 2017), Ethanolic extract of whole plant of 
Bacopamonnieri shows cytotoxicity for Dalton's lymphoma cells at a concentration of 150 $\mu \mathrm{g} / \mathrm{mL}$. Oral administration of this extract reduces the risk of solid tumor formation (Kumar et al., 1998). Ethanolic extract of Bacopamonnieri, when administered in mouse S-180 cells, results in cytotoxicity in a doseand time-dependent manner. The peak cytotoxic effect is shown at $48 \mathrm{~h}$ of administration of $550 \mu \mathrm{g} / \mathrm{mL}$. Apoptosis was associated with decreased glutathione levels in treated cells (Rohini and Devi 2008).Wholeplant ethanolic extract of $\mathrm{BM}$, when tested in sarcoma-180 culture cells, showed inhibition of cell growth with the increase in concentration of extract. The results proved that Bacopamonnieri shows anticancer effects in a dose-dependent manner (Elangovan et al. 1995). The present investigation was carried out to evaluate the anticancer activity of Bacopamonnieiri different extracts. In vitro cytotoxicity study using hct116 and caco 2 cell lines showed potent activity with acetone extract against hct116 $6.79 \mu \mathrm{g} / \mathrm{ml}$, and its value against caco2 $6.1 \mu \mathrm{g} / \mathrm{ml}$.

\section{REFERENCES}

Badr-Elden, A. M. E. (2014). In vitro enhancement of antioxidant activity, phenolic content and flavonoid content of bacopamonnieri I. Review Of Research,Vol. 4 |, (3), 1-11.

Baskaran, P., \&Jayabalan, N. (2005). Role of basal media, carbon sources and growth regulators in micropropagation of Eclipta alba-a valuable medicinal herb. KMITL Sci. J, 5(2), 469482.

Bazrafshan, N., \&Lotfi, M. M. (2016). A multiobjective multi-drug model for cancer chemotherapy treatment planning: A costeffective approach to designing clinical trials. Computers \& Chemical Engineering, 87, 226-233.

Bhusari, S., Wanjari, R., \&Khobragade, P. (2013). Cost Effective in vitro clonal propagation of
BacopamonnieriL. Penell. International Journal of Indigenous Medicinal Plants, 46(2), 1239-1244.

Calvert, P. M., \&Frucht, H. (2002). The genetics of colorectal cancer. Annals of internal medicine, 137(7), 603-612.

Chabner, B. A., \& Roberts Jr, T. G. (2005). Chemotherapy and the war on cancer. Nature Reviews Cancer, 5(1), 65.

Elangovan, V., Govindasamy, S., Ramamoorthy, N., \&Balasubramanian, K. (1995). In vitro studies on the anticancer activity of Bacopamonnieri. Fitoterapia, 66(3), 211-215.

Ferlay, J.; Soerjomataram, I.; Dikshit, R.; Eser, S.; Mathers, C.; Rebelo, M.; Parkin, D.M.; Forman, D.; Bray, F. Cancer incidence and mortality worldwide: Sources, 
methods and major patterns in globocan 2012.Int. J. Cancer 2015,136, E359-E386.

Haque, S.M., Chakraborty, A. Dey, D., Mukherjee, S. , Nayak, S. and Ghosh, B. (2017).Improved micropropagation of Bacopamonnieri (L.) Wettst. (Plantaginaceae) and antimicrobial activity of in vitro and ex vitro raised plants against multidrug-resistant clinical isolates of urinary tract infecting (UTI) and respiratory tract infecting (RTI) bacteria.Clinical Phytoscience,3:17.

Huang, S., Wu, B., Li, D., Zhou, W., Deng, G., Zhang, K., \& Li, Y. (2014). Knockdown of astrocyte elevated gene- 1 inhibits tumor growth and modifies microRNAs expression profiles in human colorectal cancer cells. Biochemical and biophysical research communications, 444(3), 338345.

Hussien, N. A., Mohammed, N. G., Mohammed, D. I., \& El-Ghor, A. A. (2013). Antiproliferative and apoptotic effects of grape seed extract on human colon cancer cell line HCT116. Advances in Natural and Applied Sciences, 7(3), 206215.

Jagetia, G. C., \& Rao, S. K. (2006). Evaluation of the antineoplastic activity of guduchi (Tinosporacordifolia) in Ehrlich ascites carcinoma bearing mice. Biological and Pharmaceutical Bulletin, 29(3), 460-466.

Kahol, A. P., Singh, T., Tandon, S., Gupta, M. M., \&Khanuja, S. P. S. (2004). U.S. Patent No. 6,833,143. Washington, DC: U.S. Patent and Trademark Office.

Kapil, S. and V. Sharma 2014. In Vitro Propagation of BacopaMonneri: An Important Medicinal Plant, Int. J. Curr. Biotechnol., 2(1): 7-10.

Kaur, J., Nautiyal, K. and Pant, M. 2013:In vitro propagation of Bacopamonnieri(L.) Wettst A medicinally priced herb. Int. J. Curr. Microbiol. App. Sci (2013) 2(8): 131-13.

Kumar, E. P., Elshurafa, A. A., Elango, K., Subburaju, T., \& Suresh, B. (1998). Cytotoxic And AntiTumour Properties of Ethanolic Extract of BacopaMonnieri(L) Penn. Ancient science of life, 17(3), 228.

Lakhera, K., Kumar, A., Rani, A., Dixit, R., \& Rana, S. (2018). Plant tissue culture and its application. Bulletin of Pure and Applied Sciences.

Mallick, M. N., Khan, W., Parveen, R., \& Ahmad, S. (2017). Exploring the cytotoxic potential of triterpenoids-enriched fraction of Bacopamonnieri by implementing in vitro, in vivo, 
and in silico approaches.

Pharmacognosy magazine, 13(Suppl 3), S595.

Mohanta, Y. K., \&Sahoo, S. (2014). In vitro culture of highly valuable medicinal plant Bacopamonnieri (L.) Penn. for rapid and mass multiplication. International Journal of Pharmaceutical Science Invention, 3(1), 41-45.

Mossman, T. (1983) Rapid colorimetric assay for cellular growth and survival: application to proliferation and cytotoxicity assays. J Immunol Meth.,65,55-63.

Murashige, T., \& Skoog, F. (1962). A revised medium for rapid growth and bio assays with tobacco tissue cultures.

Physiologiaplantarum, 15(3), 473-497.

Murthy, H. N., Hahn, E. J., \&Paek, K. Y. (2008). Adventitious roots and secondary metabolism. Chinese Journal of Biotechnology, 24(5), 711-716.

Murthy, H.N., Lee, E.J. and Paek, K.Y. (2014).

Production of secondary metabolites from cell and organ cultures: strategies and approaches for biomass improvement and metabolite accumulation. Plant Cell, Tissue and Organ Culture 118: 1-16.

Naik, P. M., Godbole, M., Nagella, P., \& Murthy, H. N. (2017). Influence of different media, medium strength and carbon sources on adventitious shoot cultures and production of bacoside $A$ in Bacopamonnieri (L.). Ceylon Journal of Science, 46(4), 97104.

Peng, L., Zhou, Y., Kong, D. Y., \& Zhang, W. D. (2010). Antitumor activities of dammaranetriterpenesaponins from Bacopamonniera. Phytotherapy Research, 24(6), 864-868.

Pérez-Herrero, E., \&Fernández-Medarde, A. (2015). Advanced targeted therapies in cancer: Drug nanocarriers, the future of chemotherapy. European journal of pharmaceutics and biopharmaceutics, 93, 52-79.

Phrompittayarat, W., Putalun, W., Tanaka, H., Jetiyanon, K., Wittaya-areekul, S., \&Ingkaninan, K. (2007). Comparison of various extraction methods of Bacopamonnieri. Naresuan University Journal: Science and Technology (NUJST), 15(1), 29-34.

Prakash, N. S., Sundaram, R., \&Mitra, S. K. (2011). In vitro and in vivo anticancer activity of bacoside a from whole plant of BacopaMonnieiri(Linn). Am J PharmacolToxicol, 6(1), 11-19.

Rao, S. R., \&Ravishankar, G. A. (2002). Plant cell cultures: chemical factories of secondary 
metabolites. Biotechnology advances, 20(2), 101-153.

Rohini, G., \& Devi, C. S. (2008). Bacopamonniera extract Induces apoptosis in murine sarcoma cells (S- 180). Phytotherapy Research: An International Journal Devoted to Pharmacological and Toxicological Evaluation of Natural Product Derivatives, 22(12), 1595-1598.

Sarin, R. (2005). Useful metabolites from plant tissue cultures. Biotechnology, 4(2), 79-93.

Sharma, N. (2005). Micropropagation of Bacopamonneiri L. Penn.-an important medicinal plant (Doctoral dissertation, M. Phil. Thesis. Thapar Institute of Engineering and Technology Patiala, India).

Shashi, B., Jaswant, S., Madhusudana, R. J., Kumar, S. A., \&Nabi, Q. G. (2006). A novel lignan composition from Cedrusdeodara induces apoptosis and early nitric oxide generation in human leukemia Molt-4 and HL-60 cells. Nitric oxide, 14(1), 72-88.

Shishodia S, Chaturvedi MM, Aggarwal BB. 2007. Role of curcumin in cancer therapy. CurrProbl Cancer. 31:243-305.

Showkat, P., Zaidi, Y., Asghar, S., \& Jamaluddin, S. (2010). In vitro Propagation and Callus Formation of Bacopamonnieri
(L.) Penn. Plant Tissue Culture and Biotechnology, 20(2), 119125

Soundararajan, T., \&Karrunakaran, C. M. (2011). Micropropagation of Bacopamonnierithrough protoplast. Asian J Biotechnol, 3(2), 135-152.

Srivastava, P., Tiwari, K. N., \& Srivastava, G. (2017). Effect of different carbon sources on in vitro regeneration of BrahmiBacopamonnieri (L.) An important memory vitalizer. Journal of Medicinal Plants, 5(3), 202-208.

Tripathi, Leena, and JaindraNathTripathi. "Role of biotechnology in medicinal plants." Tropical Journal of Pharmaceutical Research 2, no. 2 (2003): 243-253.

Verpoorte, R., Contin, A., \& Memelink, J. (2002). Biotechnology for the production of plant secondary metabolites. Phytochemistry reviews, 1(1), 13-25.

Warrier, P. K. (1993). Indian medicinal plants: a compendium of 500 species (Vol. 5). Orient Blackswan. 